\title{
Administrative Justice in Ukraine and Space Law
}

\author{
Igor Smolij \\ Judge of the Kyiv District Administrative Court (Kyiv, Ukraine) \\ E-mail: inbox@adm.ki.court.gov.ua
}

The paper examines the relationship between administrative justice in Ukraine and space law. The urgent issues of Ukraine's compliance with international obligations in administrative justice are directly related to the legal regulation of international cooperation in the development and use of outer space. The author declares that international cooperation in the field of administrative justice is part of Ukraine's international cooperation in the exploration and use of outer space. It implies the strict adherence to universally accepted principles of international law and space law. It was emphasized that international cooperation in the field of space is a joint and coordinated activity of the authorized bodies of different countries in order to realize the interests of the individual, society, the state and the international community in certain spheres of social activity. It is regulated by international and national space law.

Keywords: space law; administrative justice; international obligations; international cooperation; international law.

\section{Адміністративне судочинство в Україні і космічне право}

\section{Смолій, Ігор Володимирович}

\author{
суддя окружного адміністративного суду міста Києва (Київ, Україна)
}

\begin{abstract}
У статті розглянуто зв'язок між адміністративним судочинством в Україні і космічним правом. Розглянуті в статті актуальні питання дотримання Украӥною міжнародних зобов'язань в адміністративному судочинстві мають пряме відношення до правового регулювання міжнародного співробітництва по освоєнню і використанню космічного простору. Зазначено, щзо міжнародне співробітництво у сфері адміністративного судочинства є частиною міжнародного співробітництва України в дослідженні і використанні космічного простору, та передбачає неухильне дотримання загальновизнаних приниипів міжнародного права і космічного права. Наголошено, щчо міжнародне співробітництво у галузі космосу - ие спільна та узгоджена діяльність уповноважених органів різних країн щзодо реалізації інтересів особистості, суспільства, держави та міжнародного співтовариства у певних сферах суспільної діяльності, регульована нормами міжнародного і внутрішньодержавного космічного права.

Ключові слова: космічне право; адміністративне судочинство; міжнародні зобов'язання; міжнародне співробітництво; міжнародне право.
\end{abstract}

(C) Smolij, Igor, 2018 
Received: January 18, 2018; accepted: February 13, 2018

Advanced Space Law, Volume 1, 2018: 91-97.

https://doi.org/10.29202/as1/2018/1/11

\section{Постановка проблеми}

Термін «космічне право» в сучасній юриспруденції охоплює різні галузі права, такі як адміністративне право, фінансове право, екологічне право, кримінальне право, трудове право і комерційне право. Космічне право стимулює розвиток правових основ космічної діяльності на рівні окремих держав. Україна, яка має потужну інтелектуальну та технологічну базу для освоєння космосу, однією з перших прийняла Закон «Про космічну діяльність». Закон визначає загальні правові засади здійснення космічної діяльності в Україні та під юрисдикцією України поза ії межами [Закон України, 1997].

Дослідницькі, довідкові та освітні програми в галузі космічного права підтримують авторитетні наукові журнали. Наприклад,

1. Журнал «Космічне право» (Journal of Space Law). Це перший у світі журнал, що цілком присвяченим космічному праву. Він видається з 1973 року Університетом Міссісіпі, США.

2. «Повітряне і космічне право» (Air \& Space Law). Журнал видається з 1975 року компанією Wolters Kluwer Law \& Business (Нідерланди). Це провідний світовий постачальник інформації для юристів.

3. «Аннали повітряного і космічного права» (Annals of Air and Space Law). Журнал видається з 1976 року Інститутом і Центром повітряного і космічного права, юридичного факультету університету Макгілла (McGill University), Монреаль, Канада.

4. «Космічна політика» (Space Policy). Журнал видається однією з найбільших видавничих компаній світу, Elsevier Ltd. Редакція журналу розташована у Великій Британії.

Всі вищеназвані журнали індексуються в базах Web of Science i Scopus.

Журнал «Advanced Space Law», що заснований в Україні у 2018 році, починає друкувати дослідження що впливають на космічне право. У своєму дослідженні ми розглянемо актуальні питання дотримання Україною міжнародних зобов'язань в адміністративному судочинстві. Україна як правова демократична держава, яка взяла курс на європейську інтеграцію, сьогодні будує суспільство, засноване на принципі верховенства права, що закріплений у ч. 1 ст. 8 Конституції України [Конституція України, 1996]. Дія принципу верховенства права має на меті встановлення певних меж діяльності держави в ім'я захисту прав людини, викорінення будь-якого свавілля. Власне, основоположні права та свободи людини визначають зміст і спрямованість розуміння верховенства права як доктрини, принципу та ідеалу [Принцип, 2016]. Статтею 3 Конституції України «людина, її життя і здоров'я, честь і гідність, недоторканність і безпека визнаються в Україні найвищою соціальною цінністю. Права і свободи людини та їх гарантії визначають зміст і спрямованість діяльності держави. Держава відповідає перед людиною за свою 
діяльність. Утвердження і забезпечення прав і свобод людини є головним обов'язком держави» [Конституція України, 1996].

Своєю чергою, захист законності та правопорядку в державі, конституційних прав i свобод людини визнається основним завданням судової гілки влади, яка покликана підтримувати рівновагу у суспільстві й захищати зазначені в Конституції України цінності.

3 огляду на те, що дотримання рішень міжнародних інституцій у рамках міжнародно-правового співробітництва та інтеграції України у європейське співтовариство засвідчує перед міжнародними партнерами правильність вибраного шляху розбудови правової та демократичної держави, метою наукової статті є дослідження зв'язку між адміністративним судочинством в Україні і космічним правом. Розглянуті в статті актуальні питання дотримання Україною міжнародних зобов'язань в адміністративному судочинстві мають пряме відношення до правового регулювання міжнародного співробітництва по освоєнню і використанню космічного простору.

\section{Виклад основного матеріалу}

Починаючи розгляд досліджуваного питання, варто навести роздуми видатних учених щодо правової реформи, що наразі триває в Україні. Так, на слушну думку Юрія Аленіна, формування і розвиток правової держави, забезпечення прав і свобод людини, відповідальності держави перед громадянами та громадян перед суспільством, нерозривно пов'язані із зміцненням правової основи держави, а у суспільному житті 3 неухильним дотриманням законності, підвищенням рівня боротьби зі злочинністю. Правова реформа, яка здійснюється в Україні, наголошує науковець, повинна привести судову систему, а також всі галузі права, у відповідність до норм Конституції з урахуванням тих соціально-політичних змін, які мають місце в суспільстві [Аленин, 2002: 3].

Стратегією реформування судоустрою, судочинства та суміжних правових інститутів на 2015-2020 роки серед першочергових реформ, які необхідно впровадити, особлива увага приділяється судовій реформі, метою якої є утвердження такого правопорядку, який грунтується на високому рівні правової культури в суспільстві, діяльності всіх суб' єктів суспільних відносин на засадах верховенства права та захисту прав і свобод людини, а в разі їх порушення — справедливого їх відновлення в розумні строки. Судова система України та суміжні правові інститути існують для захисту прав, свобод та законних інтересів людини і громадянина, прав та законних інтересів юридичних осіб, інтересів держави шляхом своєчасного, ефективного і справедливого вирішення правових спорів на засадах верховенства права [Про Стратегію, 2015].

Унаслідок реалізації цієї Стратегії судова система України та суміжні правові інститути працюватимуть, керуючись принципом верховенства права, ефективно, продуктивно та скоординовано, стануть підзвітними громадянам України, вільними від будь-якого політичного впливу та відповідатимуть стандартам і передовим практикам Свропейського Союзу [Про Стратегію, 2015].

Варто зазначити, що положення цього документа повною мірою стосуються і міжнародного співробітництва. Венеціанська комісія у своїй доповіді «Про верховенство права» (Venice Commission: the Rule of Law) визначає шести основних елементів верховенства права [European Commission, 2016]:

1. Законність, в тому числі прозорий, підзвітний і демократичний порядок введення законів у дію; 
2. Правова певність;

3. Заборона свавілля;

4. Доступ до правосуддя у незалежних і неупереджених судах, в тому числі судовий контроль за адміністративними актами;

5. Дотримання прав людини;

6. Недискримінація та рівність перед законом.

Перелічені елементи покладено в основу конституційних і законодавчих положень i судової практики як на національному, так і міжнародному рівнях.

Відповідно до підходів Венеціанської комісії виділяють такі складові верховенства права [European Commission, 2016]:

1. Доступ до закону (положення закону повинні бути зрозумілими, ясними та передбачуваними);

2. Вирішення питань про юридичні права повинно, як правило, здійснюватися на підставі закону, а не за розсудом;

3. Рівність перед законом;

4. Влада повинна реалізовуватися відповідно до закону, справедливо та розумно;

5. Права людини повинні бути захищені;

6. Повинні бути наявні засоби для врегулювання спорів без невиправданих витрат та відстрочок;

7. Наявність справедливого суду;

8. Держава повинна дотримуватися своїх зобов'язань у рамках як міжнародного, так і національного права.

Адміністративне судочинство - це діяльність адміністративних судів щодо розгляду і вирішення адміністративних справ у порядку, встановленому Кодексом адміністративного судочинства України (ст. 4) (далі - КАС України). Відповідно до ст. 2 КАС України завданням адміністративного судочинства $є$ справедливе, неупереджене та своєчасне вирішення судом спорів у сфері публічно-правових відносин з метою ефективного захисту прав, свобод та інтересів фізичних осіб, прав та інтересів юридичних осіб від порушень з боку суб'єктів владних повноважень [Кодекс, 2005]. Отже, очевидно, що адміністративне судочинство також має будуватися на принципі верховенства права. Також Кодексом адміністративного судочинства України визначено напрями міжнародного співробітництва у сфері адміністративного судочинства.

Це підтверджується також і Законом України «Про судоустрій і статус суддів» від 02 червня 2016 року № 1402-VIII, яким передбачено, що суд здійснює правосуддя на засадах верховенства права, забезпечує кожному право на справедливий суд та повагу до інших прав і свобод, гарантованих Конституцією і законами України, а також міжнародними договорами, згода на обов'язковість яких надана Верховною Радою України (ст. 2). Крім того, вище зазначеним Законом встановлено, що судові рішення інших держав, рішення міжнародних арбітражів, рішення міжнародних судових установ та аналогічні рішення інших міжнародних організацій щодо вирішення спорів є обов'язковими до виконання на території України за умов, визначених законом, а також відповідно до міжнародних договорів, згода на обов'язковість яких надана Верховною Радою України (ст. 13) [Про судоустрій, 2016]. 
Наявна сьогодні низка проблем, пов'язаних з міжнародним співробітництвом у сфері адміністративного судочинства як частиною міжнародного співробітництва держави в цілому, потребує нагального вирішення, а власне адміністративне судочинство - удосконалення. Також актуальним $є$ питання дотримання міжнародних зобов'язань в адміністративному судочинстві України. 3 цього приводу точаться постійні дискусії як представників судової гілки влади, так і вчених-юристів.

Міжнародне співробітництво у галузі космосу - це спільна та узгоджена діяльність уповноважених органів різних країн щодо реалізації інтересів особистості, суспільства, держави та міжнародного співтовариства у певних сферах суспільної діяльності, регульована нормами міжнародного і внутрішньодержавного космічного права.

3 огляду на те, що міжнародне співробітництво у сфері адміністративного судочинства є частиною міжнародного співробітництва України у галузі космосу, воно передбачає неухильне дотримання загальновизнаних принципів міжнародного права і космічного права. Тому наразі актуальним вбачається дотримання нашою країною міжнародних зобов'язань в адміністративному судочинстві. Варто вказати, що міжнародне співробітництво в галузі космосу в цілому і міжнародне співробітництво у сфері адміністративного судочинства зокрема суттєво впливають на авторитет нашої держави у світі. Своєю чергою, ст. 15 Закону України «Про міжнародні договори України» від 29 червня 2004 року № 1906-IV [Про міжнародні договори, 2004]. Передбачено, що чинні міжнародні договори України, що пов’язані з дослідженням і використанням космічного простору, підлягають сумлінному дотриманню Україною відповідно до норм міжнародного права і космічного права. Згідно з принципом сумлінного дотримання міжнародних договорів Україна виступає за те, щоб й інші сторони міжнародних договорів України неухильно виконували свої зобов'язання за цими договорами.

Отже, сумлінне дотримання чинних міжнародних договорів, що пов'язані 3 дослідженням і використанням космічного простору, передбачає виконання зобов'язань обома сторонами. Це і буде запорукою успіху дотримання міжнародних зобов'язань нашою країною, зокрема і в адміністративному судочинстві України, що, своєю чергою, сприятиме ефективному міжнародному співробітництву у сфері адміністративного судочинства.

Порядок укладення, виконання та припинення дії міжнародних договорів України передбачений розділом III. Дотримання і виконання міжнародних договорів Закону України «Про міжнародні договори України» [Про міжнародні договори, 2004]. Зокрема, ст. 17 встановлено, що загальний нагляд за виконанням міжнародних договорів України, в тому числі й іншими їх сторонами, здійснює Міністерство закордонних справ України. На запит органів, які застосовують міжнародні договори України, Міністерство закордонних справ України надає інформацію з питань, що виникають у зв'язку з виконанням міжнародних договорів України. Крім того, ст. 19. Закону передбачено, що якщо міжнародним договором України, який набрав чинності в установленому порядку, встановлено інші правила, ніж ті, що передбачені у відповідному акті законодавства України, то застосовуються правила міжнародного договору.

У Постанові Пленуму Вищого спеціалізованого суду України з розгляду цивільних і кримінальних справ «Про застосування судами міжнародних договорів України при здійсненні правосуддя» від 19 грудня 2014 р. № 13 йдеться, зокрема, про те, що міжнародні договори України, які набрали чинності, не лише сприяють розвитку міждержавного співробітництва у різних сферах суспільного життя та належному забезпеченню національних інтересів, здійсненню цілей, завдань і принципів зовнішньої політики 
України, закріплених у Конституції України, а й можуть завдяки своєму пріоритету над нормами відповідних законодавчих актів України змінювати регулювання правових відносин, установлених законодавством України [Про застосування, 2014].

Окремо слід вказати на виконання рішень Європейського суду з прав людини на території нашої держави, яке є обов'язковим і невідкладним. Тобто, Свропейському суду 3 прав людини відведено важливу роль в організації міжнародного співробітництва у сфері адміністративного судочинства.

Також, для міжнародного співробітництва важлива компетенція Міжнародного суду ООН та визнання державами його юрисдикції.

\section{Висновки}

Підсумовуючи, зазначимо, що судова система України та суміжні правові інститути існують для захисту прав, свобод та законних інтересів людини і громадянина, прав та законних інтересів юридичних осіб, інтересів держави шляхом своєчасного, ефективного і справедливого вирішення правових спорів на засадах верховенства права.

Дотримання міжнародних зобов’язань в адміністративному судочинстві України передбачає, що міжнародне співробітництво у сфері адміністративного судочинства має здійснюватися задля підтримки розвитку дієвої, прозорої, передбачуваної та ефективно діючої системи адміністративних судів в Україні. Завдяки міжнародному співробітництву повинно відбуватись удосконалення функціональних якостей основних сфер адміністративного судочинства, у тому числі шляхом ознайомлення із провідним досвідом країн-членів $Є С$, а також підвищення його інституційної спроможності, що, своєю чергою, сприятиме підсиленню верховенства права.

\section{Література}

Аленин, Юрий. Проиессуальные особенности производства следственных действий. Одесса: Центрально-Украинское издательство, 2002.

Закон України «Про космічну діяльність». Відомості Верховної Ради Украӥни (ВВР), 1 , 1997, Ст. 2.

Кодекс адміністративного судочинства України. Від 06.07.2005 № 2747-IV. http://zakon2. rada.gov.ua/laws/show/2747-15

Конституція України: Закон від 28.06.1996 № 254к/96-ВР. Відомості Верховної Ради України (ВВР). 30, 1996. Ст. 141.

Принцип верховенства права. Справедливий Суд, 2016. http://akrsud.kharkiv.ua/printsipverhovenstva-prava/

Про застосування судами міжнародних договорів України при здійсненні правосуддя. Постанова Пленуму Вищого Спеціалізованого Суду України з розгляду цивільних і кримінальних справ від 19.12.2014 № 13. http://zakon2.rada.gov.ua/laws/ show/v0013740-14

Про міжнародні договори України. Закон України від 29.06.2004 № 1906-IV. http:// zakon5.rada.gov.ua/laws/show/1906-15

Про Стратегію реформування судоустрою, судочинства та суміжних правових інститутів на 2015-2020 роки. Указ Президента України від 20.05.2015 № 276/2015. http://zakon5.rada.gov.ua/laws/show/276/2015 
Про судоустрій і статус суддів. Закон від 02.06.2016 № 1402-VIII. Відомості Верховної Ради (ВВP). 31, 2016. ст. 545.

European Commission For Democracy Through Law (Venice Commission). Rule of law checklist, adopted by the Venice Commission at its $106^{\text {th }}$ Plenary Session (Venice, 11-12 March 2016). http://www.venice.coe.int/webforms/documents/?pdf=CDL$\mathrm{AD}(2016) 007-\mathrm{e}$

\section{[ㅁ] References}

Alenyn, Yuryi. Protsessualnble osobennosty proyzvodstva sledstvennblkh deistvyi. Odessa: Tsentralno-Ukraynskoe yzdatelstvo, 2002.

Zakon Ukrainy «Pro kosmichnu diialnist». Vidomosti Verkhovnoi Rady Ukrainy (VVR), 1, 1997, St. 2.

Kodeks administratyvnoho sudochynstva Ukrainy. Vid 06.07.2005 № 2747-IV. http://zakon2. rada.gov.ua/laws/show/2747-15

Konstytutsiia Ukrainy: Zakon vid 28.06.1996 № 254k/96-VR. Vidomosti Verkhovnoi Rady Ukrainy (VVR). 30, 1996. St. 141.

Pryntsyp verkhovenstva prava. Spravedlyvyi Sud, 2016. http://akrsud.kharkiv.ua/printsipverhovenstva-prava/

Pro zastosuvannia sudamy mizhnarodnykh dohovoriv Ukrainy pry zdiisnenni pravosuddia. Postanova Plenumu Vyshchoho Spetsializovanoho Sudu Ukrainy z rozghliadu tsyvilnykh i kryminalnykh sprav vid 19.12.2014 № 13. http://zakon2.rada.gov.ua/laws/ show/v0013740-14

Pro mizhnarodni dohovory Ukrainy. Zakon Ukrainy vid 29.06.2004 № 1906-IV. http://zakon5. rada.gov.ua/laws/show/1906-15

Pro Stratehiiu reformuvannia sudoustroiu, sudochynstva ta sumizhnykh pravovykh instytutiv na 2015-2020 roky. Ukaz Prezydenta Ukrainy vid 20.05.2015 № 276/2015. http:// zakon5.rada.gov.ua/laws/show/276/2015

Pro sudoustrii i status suddiv. Zakon vid 02.06.2016 № 1402-VIII. Vidomosti Verkhovnoi Rady (VVR). 31, 2016. st. 545.

European Commission For Democracy Through Law (Venice Commission). Rule of law checklist, adopted by the Venice Commission at its $106^{\text {th }}$ Plenary Session (Venice, 11-12 March 2016). http://www.venice.coe.int/webforms/documents/?pdf=CDL$\mathrm{AD}(2016) 007-\mathrm{e}$ 